\title{
ХАРАКТЕРИСТИКА ОСОБЕННОСТЕЙ ПИЩЕВОГО ПОВЕДЕНИЯ И ЭМОЦИОНАЛЬНО-ЛИЧНОСТНЫХ ОСОБЕННОСТЕЙ ДЕТЕЙ С ИЗБЫТОЧНОЙ МАССОЙ ТЕЛА И ОЖИРЕНИЕМ
}

\author{
А.С. Аджигельдиева, Н.Э. Ахундзаде \\ БУ ВО ХМАО-Югры “Сургутский государственный университет», г. Сургут
}

На сегодняшний день, ожирение является одним из самых распространенных неинфекционных заболеваний, которое приобрело характер эпидемии. Своевременное выявление и лечение ожирения в детском возрасте является залогом снижения заболеваний сердечно-сосудистой, эндокринной, опорно-двигательной систем у людей старшего возраста. Изменения пищевого поведения формируются у детей с ожирением в первые 2-3 года от момента набора массы тела, вслед за которыми изменяются эмоционально-личностные характеристики, что способствует дальнейшему прогрессированию ожирения.

ЦЕЛЬ ИССЛЕДОВАНИЯ. Дать оценку субъективным ощущениям пациентов с ожирением по восприятию себя и своей массы в социуме, выявить особенности пищевого поведения у детей.

МАТЕРИАЛЫ И МЕТОДЫ. Научно-исследовательская работа выполнена на базе педиатрических отделений БУ ВО «Сургутская городская клиническая больница», МБОУ «Сургутская технологическая школа». В исследование было включено 84 подростка в возрасте от 12 до 17 лет с избыточной массой тела и ожирением (SDS ИMT >+1,0). Для достижения поставленных целей проведен сбор анамнеза, антропометрическое исследование, использовали визуально-аналоговую шкалу (VAS - Visual Analogue Scale; BAШ, русс.) и визуальные нормативы правильного питания.

РЕЗУЛЬТАТЫ ИССЛЕДОВАНИЯ. В ИсследУемоЙ группе средний возраст составил возраст $14,9 \pm 2,1$ года. Гендерные различия: девочек 43\%, мальчиков 57\%. При сборе анамнеза жизни было выявлено, что у $32 \%$ подростков наследственность по ожирению была отягощена и по материнской, и по отцовской линиям, у 48\% пациентов - с одной стороны, преимущественно, по линии матери, в 20\% случаев наследственность не была отягощена.

Оценка массы тела показала: 57\% детей имели избыточную массу тела, $43 \%$ - ожирение. В структуре ожирения: SDS ИМТ +2,0-2,5 - 36,5\% детей, SDS ИMT +2,6-3,0-59\% пациентов, SDS ИMT +3,1-3,9-4,5\% случаев, морбидное ожирение выявлено не было.

В настоящее время не существует прибора, который максимально точно отражал субъективные ощущения пациента. Визуально-аналоговая шкала для оценки пациента с ожирением является простым способом определения субъективных ощущений пациента по восприятию себя и своей массы тела. В ходе анализа визуально-аналоговой шкалы были следующие ответы (max-min):

- Насколько вы счастливы?

На 8 баллов - 25\% детей, на 3 балла - 2\%;

- Как вы оцениваете качество вашей жизни?

На 8 баллов - 27,2\%, на 1 балл - 4,5\%;

- Как вы оцениваете ваш аппетит?

На 6 баллов - 25\%, на 0 баллов - 2\%;

- Вы чувствуете угнетение, страх, травлю со стороны окружающих людей?

На 10 баллов - 2\%, на 0 баллов - 25\%;

- Вы хотите похудеть?

На 9 баллов - 22,5\%, на 0 баллов - 2\%;

- Вы действительно хорошо себя чувствуете в своем теле или нет?

На 5 баллов - 22,5\%, на 1 балл - 4,5\% детей. 


\section{СБОРНИК ТЕЗИСОВ}

XVII Российская научно-практическая конференция детских эндокринологов «Достижения науки в практику детского эндокринолога»

При анализе пищевого поведения выявлено, что 13,5\% детей придерживаются принципов правильного питания, 48\% питаются «условно» неправильно, а в 38,5\% случаев питание детей не соответствовало «здоровым» характеристикам. При оценке пищевого поведения был выявлен ряд нарушений: отсутствие завтрака у $34 \%$ подростков, большое количество легкоусвояемых углеводов в рационе питания (77\%), недостаточное употребление питьевой воды (48\%), отсутствие овощей и фруктов (25\%), употребление алкогольных и энергетических напитКОВ (18\%).

ЗАКЛЮЧЕНИЕ. В возрастной группе 12-17 лет происходит постепенное изменение восприятие своего тела, в сравнении с младшей возрастной группой, появляется понимание повышенного аппетита, ухудшение восприятия своего тела и желание похудеть. Оценка рациона питания показала высокий значительный процент «вредных» продуктов на фоне снижения потребления «здоровой» пищи на фоне нарушений режима питания. 